DOI: $10.2478 /$ aussoc-2018-0005

\title{
The Ethical Dimension of Professional Integrity in the Hungarian Child Protection System
}

\author{
Ernő BOGÁCS \\ National Office for Rehabilitation and Social Affairs, Budapest, Hungary \\ bogacs.erno@szgyf.gov.hu
}

\author{
Andrea RÁCZ \\ Eötvös Loránd University, Budapest, Hungary \\ raczandrea@tatk.elte.hu
}

\begin{abstract}
Following a discussion about ethics and social work, in this article, we will present the main results of three researches conducted in the past few years on the Hungarian child protection system. These studies highlight the professional gaps, the prejudiced beliefs related to the primary (children) and secondary (parents) client systems of child protection, the value crisis in professional mentalities, and the crisis of the profession in general. We argue that a change in mentalities and professional treatment in the operational practice requires a thorough reconsideration of the ethical dimensions of child protection to the extent of developing and introducing their own code of ethics. As the helping profession is actively involved in the transformation of the welfare state, in parallel with restructuring welfare conditions, we should reconsider how the scarce methodological framework for practice at the national level can cope with problems and how it can emancipate the clients and serve their well-being. The research results indicate that the direction of development is to create an activating and mobilizing helper system that can preserve the core values of the profession as well as adapt to social changes and reflect on the expectations of the public policy thereof.
\end{abstract}

Keywords: ethics, values, value crisis, child protection, professional integrity

\section{Introduction}

This study starts with a discussion about why social work needs ethics. Following this discussion, we present the main results of three researches conducted in recent years on the Hungarian child protection system. These studies highlight the professional gaps, the prejudiced beliefs related to the primary (children) 
and secondary (parents) client systems of child protection, the value crisis in professional mentalities, and the crisis of the profession in general. We argue that a change in mentalities and professional treatment in the operational practice really requires the reconsideration of the ethical dimensions of child protection to the extent of developing and introducing their own code of ethics.

\section{Social work and ethics}

To examine the relationship between social work and ethics, one first needs to find an answer to the question: why do we need ethics in social work? Gardner et al. (2008: 42) claim that, essentially, the recognition of any field of knowledge as a profession calls for the existence of an ethical dimension in addition to knowledge and skills. This ensures that the expertise is not used for selfish ends and against public interest. It is an appealing approach, particularly in relation to social work, as it could become (one of) the profession(s) of professions since all three conditions are so poignant (especially the ethical).

Obviously, many fields of knowledge would debate this approach, not only those that require some sophistication to justify the ethical dimension (e.g. military industry) but also those areas that appear to be ethically neutral. Furthermore, "ethical" professions such as medicine and social work may violate the ethical dimension in their practical implementation. It is important to mention this because the professions cited above may be considered to be less ethical or ethically neutral for reasons related to their implementation or practice. Speculative thinking, of course, can reveal the existence of an ethical dimension in any profession. However, it cannot be overlooked that the requirement of public interest may be appealing, but it is also controversial. Why is ethical what is socially useful? And, anyway, what does one mean by public interest? The opening question - how does social work relate to ethics - can be answered simply. That is, social work can only be considered as a profession if it has an ethical dimension. Public opinion certainly supports this attractive wording because if there is one profession which is undoubtedly viewed as in need of an ethical dimension that is social work. Nevertheless, the more critical-minded may ask: why is something that serves public interest considered ethical? What does ethics have to do with social interest and, ultimately, what is ethics?

If we take social work in a broad perspective and in historical context - at least in the Christian cultural sphere -, it can be clearly identified with the physical and mental doings of mercy. Although salvation is divine grace, that is, unattainable as a gift, faith without deeds is dead. Accordingly, in the early days of Christianity, helping other people was a natural element, an essential manifestation of the morality of living in order to please God. It is important to note that the morality 
of life perceived in this sense did not only serve individual salvation but also the building of the Body of Christ as the community of believers (the Church), pointing to the existence of important social aspects. Helping in this period was a way of being, wherefore it was more of a spontaneous than an organized activity. Even when it stopped being perceived as a way of living, helping others did not become institutionalized, even if it manifested in organized ways in different activities of the religious communities and religious orders and continued to be implemented in the deeds of faith as an attribute of moral life. Social work has developed from this practice. First, in the $19^{\text {th }}$ century, it was strongly linked to the renewal of early Christian communities' ancient traditions when some charismatic figures attempted to respond to the problems of the new social class (the proletariat). Later, social work became a state intervention (Müller 1992: 11).

In a conceptual approach, social work is viewed not as social science but a profession, and its socially constitutive and retaining roles are less pronounced. Social work is "the paid professional activity that aims to assist people in overcoming serious difficulties in their lives by providing care, protection, or counseling or through social support, advocacy and community development work" (Martin \& Pierson 2011: 493). The ethical element is, however, deductible as long as helping to overcome difficulties is an ethical category.

The question of what counts as an ethical category and ultimately what is ethics still remains. In an etymological approach, it is relatively easy to interpret the concept of ethics. In terms of content, some uncertainties could be identified (Vossenkuhl 2007: 37), and it is much more difficult to extract the concept, at least if we seek a short, summarizing definition. For example, commonsensically, ethics is used as a synonym for morality (Nyíri 2003: 13, Vossenkuhl 2007: 37), which, although incorrectly, may be considered acceptable, as the present study will also refer to this discourse. Nevertheless, it is the analyses in this paper that require the separation of ethics from other related concepts, especially that of morality.

Ethics, strictly speaking, is strongly linked to philosophy as a science; a sort of moral philosophy as long as it is interpreted in Heller's (1994) approach. One may even conclude that ethics is a philosophical discourse reflecting on morality. Its central concept and subject is morality. Any attempt to describe the essence of ethics will inevitably conflict with morality. According to dictionaries, morality is the totality of socially approved rules and their implementation to manage moral conduct and to help us assess it. Besides the discourse of dictionaries, Heller (1994) makes a similar statement on morality so as to highlight individual attitude, calling it morality. This is an important statement because morality contrary to ethics - is not a theoretical construction but a certain individual's quality of behavior that is bound to a specific time and space and often to another individual or individuals. It is the nature of a specific action or failure. Still, we are left with a few questions: what are the criteria according to which a behavior 
can be classified as correct or moral? What or who qualifies as a standard and rule for correctness? Where does the prestige of such norm or rule derive from?

\section{Value pluralism}

In the metaphysical, transcendent worldview, the answer to the previous questions is very simple: transcendence as the foundation of all correct or moral behavior. It was a satisfactory explanation and a validity criterion for the majority of the society until the Enlightenment, and it still is for a certain social stratum. After the $17^{\text {th }}$ century, however, this authority ceased to be distinct and general. More actors demanded independence in their actions, or, better yet, authority was demanded for more actors. If we accept valuableness as an alternative to correctness, value as a synonym for correct, we can state that along the described process of the history of ideas, values have become diversified, their hierarchy has changed, and the essential element of morality has become malleable. Value pluralism has gained ground with a positive effect. For example, it has enabled the unfolding of the interpretive side of ethics, which is good news for philosophers. It is less gratifying for people of action who find difficulty even in applying the rules and norms of correct and incorrect to a particular case. Once authoritative norms and rules are questioned, they become void, while new norms and rules appear which are vindicating authority. This can be a liberating phenomenon for some and may lead to uncertainty for others. However, the undoubtedly liberating experience of value pluralism and relevant eligibility also brings side effects, i.e. the loss of certainty.

The uncertainty in the choice of correct norms and rules (Vossenkuhl 2007: 46) adds up to the uncertainty in the application of those norms and rules. The difficulties of putting in practice the rule of helping people (what counts as suffering, how can "real" help be provided) begs the questions: is applying the rule of helping the suffering also a valid rule for the right conduct? Is helping the suffering the correct behavior? It may seem to be nothing but navel gazing, but the point is real: value pluralism involves the possibility of a value crisis. It should be noted that this may be an essential moment of moral development as well as that of an ethical regression. These considerations do not strive to argue for the necessity or possibility of a single moral authority but instead wish to raise awareness of the potential uncertainty resulting from value pluralism and its consequences. The existence of a declared exclusive highest value, wherefrom all other values can be derived, is grounded in faith and belief. All other modes of reasoning place the knowledge or construction of values into people, which implicitly supports value pluralism. Consistently thinking further, these methods of argument are based on unprovable premises; hence, certain moral perceptions ultimately derive from rationally unprovable fundamental beliefs, that is, they 
are based on belief, or choice dependent on the degree of proof. It also applies to those reasoning modes that declare the existence of exclusively proclaimed values and intend to prove these statements with the help of rational arguments.

\section{Value pluralism and social work}

In respect of social work, all of this is important because, as a result of the empirical and historical fact of value pluralism, moral considerations that constitute one set of conditions for social work may vary depending on current politics and social policy, professional expectations, and personal beliefs. Social workers possess no highest value or value system recognized by all, wherefrom correct behavior could be inferred and applied to specific cases. Social work may require professional ethics in this context. The dilemma is twofold: 1) What is the value to pursue? 2) Is the behavior in accordance with the rules or norms determined by the value? Accordingly, the function of social work ethics is twofold: 1) to determine the behavioral rules and norms of correct social work; 2) to prepare the application options for behavioral rules and norms (facilitating the application of norms) (Márfai 2017: 16).

\section{Professional ethics}

Despite the argument outlined above, which describes the difficulty of the definition of ethical values demanding general and exclusive validity, there is a constant endeavor to develop and declare such an ethics. As for the modern era, it is sufficient to mention human rights or children's rights as recorded in international agreements. The values contained therein are legally binding, so the social workers as citizens and as paid employees, on the other hand, must take these into account in their work. The suggestion is understandable: why should there be a specific professional code of ethics for social work when social work is directly or indirectly regulated by human rights, the constitution and specific legislation, methodological recommendations, standards, technical programs, and job descriptions of the individual states. Ethics, human rights, etc. focus on the same subject in different approaches: to define and describe value (Beran 2007: 83-93). They may be interpreted as ethics. Human rights serve as the first function of ethics in social work, while the governing legislation and the other regulations as the second function. The reasons for a separate professional ethics of social work are as follows: the first is general (human rights, the constitution), while the other (legislation, standards) is concrete. In order to facilitate a professional's decision, an optimal level of generalization and deduction may justify the preparation of professional ethics. On the one hand, human rights or constitutions are too general, and they may not necessarily coincide with a 
certain social worker's moral convictions. A set of intermediate deduction of norms and rules is required that can both directly and identifiably apply to social work but also facilitate the relationship with the "unique person" through their profession (social work) by its identified specific subject (social work values) (Heller 1996: 17).

Relative to the question of why a social worker needs ethical guidance, it may be worth investigating whose interests these morally impeccable actions serve: the social worker's or the client's. Not only the orientation of social work appears to be at the center of this issue but also its ethical dimension. This ethical dimension is no longer equated with the correct behavioral norms. This is the application phase. The standards and rules of acceptable conduct are known and partly accepted, but because of their rivalry or interpretation their application requires decision making. Although it seems obvious, the client's interest is questionable, and not only because of a different definition of needs or as part of a thinking process (see Krémer 2009: 207-208). Müller (1992) is of the opinion that at the beginning of the development of social work the objective was not to help the individual but to implement a certain social interest. We have seen that the concept of social work is not necessarily linked to the social element in a constitutive sense, while in relation to ethics it emerges again and again. Why is this condition so stubborn? Is it because the individual cannot exist without society, wherefore she/he should be protected? In fact, the individual is usually forced into communal existence simply because she/he is not alone. Thus, people are organized into communities in some way to survive. This fact may lead to the conclusion that humans are essentially social beings, and satisfying their needs and developing their talents require social existence; but this is as verifiable or deniable a theory as that of a person who basically seeks love and power. However, based on these facts, that is, that the individual shares a living space with several other individuals and that people get organized into smaller or larger communities in order to ensure mutual survival, it is a fundamentally appropriate argument for the social aspects of ethics to gain emphasis.

Community life produces a variety of organizational forms depending on the number of individuals and the complexity of interactions among them. One of these is the state. The state has diverse tasks to organize and manage society for the individual's survival, and one of its priorities is to cater for the social needs of individuals and communities (Torma 2016: 5). Reverting to the historical contemplations, evidently, the state has been taking over more and more functions in this field after the Enlightenment (Müller 1992). The question is why this is regarded as important by the people in power. According to a harsh opinion, it was to maintain the people's capability for labor and offspring in the industrial reserve army (Müller 1992: 9). After the universal suffrage has been adopted, it may be assumed that the state's gaining ground in the social field is due to 
political reasons. Today, when productive work and work in general have been transformed, maintaining the industrial reserve army poses no interest (machines make human labor unnecessary in areas without some expertise); yet, the reserve army becomes indispensable in other contexts, namely as a voter reserve army, which could be redefined as a useful base in the endeavor to acquire and hold power. This approach may seem rather cynical - so, we assume that politics is a profession, which means it has an ethical dimension. Moreover, the actors of this profession keep public interest in mind, and they are no more self-serving like the representatives of journalism. However, the relativity of ethics may question traditional values in this case as well, especially social values, given that they are tied to social interest that the state should represent. This can create a situation that brings the social worker to a crossroad: social value or the client's interest, social interest or his/her own values. The state intervention - in spite of its public interest - may thus give rise to situations that are incompatible with the interests of individuals in need of assistance or a social worker's values. The social worker may need ethical support in this situation.

\section{Social interest and client interest}

The intention to suppress the personal nature of social work relates to social expectations to enforce a formalized helping management (Pierson \& Thomas 2011: 496, Parrot 2010: 2). One element of this intention is the development and application of policies, protocols, standards, and indicators used in the world of business to promote efficiency and measurability. Another step would transform the social worker into a mediator of ready services (administrator). The ethical dimension of this activity does not even arise when demand and service overlap. A decision-making situation occurs when the appropriate services are not able to cover the demand or the amount of services is limited (Parrot 2010: 4-5). The administrator feature as a social or professional requirement in this case conflicts with the classic helper attitude in the tension to find the right norm of conduct. Only a moral decision can ease the tension. In the above, choosing standards of good conduct presents a typical challenge for the social worker. More often, the application of the interiorized or adopted rules poses difficulties in individual cases (even in establishing ranking). Here, it is not the value systems that compete with each other. Adapting the approved values and rules to life situations may require support.

The conflict of society and his/her own values, social interests and client's interests, competing values and loyalty are all moral decision, and this requires guidance. Social work may need "ethics" in this sense. 


\section{The issue of professional integrity in the research of child protection}

Historically, especially in the second half of the $20^{\text {th }}$ century, social work went through several changes in terms of organizational context, and the wider context of socio-economic and political environment. Asquith et al. (2005), however, highlight that the most important principles and values on which social work is based on have been able to remain constant even though they are very vulnerable in practice. Sárkány (2011) claims that the profession of social work is both a value-driven science and a profession, where navigation relies on the values of the client system and the society's current system of values. What appears as a fundamental dilemma in social work is the question of the dual mandate, on the one hand, as the representation of society and the given institution seeking legally and economically profitable solutions, while, on the other hand, as the representation of the client in need of help. The social worker, therefore, mediates between client and society while functioning as a social subsystem. This means the coexistence of the helping-supporting and the standard promoting-controlling functions (Pataki 2008, Sárkány 2011). Sárkány (2011) raises the interpretational possibility of the triple mandate following Staub-Bernasconi, that is, the existence of an independent profession requires scientific methodology and ethics as well. The protection of human rights and social justice are fundamental as two ethical standards as well as requirements to be enforced. In this sense, social work is also a profession of human rights, whose central task is to protect rights and support interests. The preservation of fundamental values is important because it can contribute to the professionalization of the vocation, to the delimitation of its own framework in relation to other vocations. Concerning theories dealing with professionalization, vocations can be classified into two types: 1) how vocation trends develop; 2) what characteristics certain vocations have, including what features a given vocation has, what activities it performs in the public interest, how it develops self-interest, and what it identifies with (Nagy 2009: 87). Within this second group, the so-called social function-oriented trends are important to us, which belong to Durkheim, Parsons, and start from social needs that a particular profession responds to. This is a kind of mission since it is in the service of the common good founded on the social division of labor as well as shared responsibility and solidarity (Nagy 2009: 92).

However, the people in social work training and the professionals themselves assume the low prestige of the vocation (Fónai et al. 1996, Grand 2011, Papp \& Rácz 2015). The volatility of the values of the profession is indicated in the example that students typically do not take on political appearances, advocacy activities, decision preparation work and do not consider important tasks that aim to change the functioning of society and social policy (Nagy 2011: 110). 
Primarily, this requires not intellect or high qualifications, but capabilities and skills. Society's image of the profession does not promote the clarification of the boundaries of the profession - not only because they know little about it but as people's views on social work and child protection are significantly influenced by the associated scandals, especially those related to children. Several such events took place in our country in the previous years. We should emphasize the importance of ethics in social work as it provides principles and values for social workers, a kind of moral code set, and in this sense it can be used as a synonym for ethics and value. However, ethics is often used as the totality of regulations and standards that govern the conduct of professionals, that is, typically related to the regulation and monitoring of professional activities. The international discourse emphasizes more and more that the code of ethics is a document that governs conduct, while the helping profession's core values appear to be less important; hence, the legislation has become more important than the promotion of values in the practical operation (Al Asquith et al. 2005). Excessive bureaucracy, increasing administrative burdens for the profession clearly lead to value conflicts for the helpers. Zastrow draws attention to the fact that the bureaucratic systems are impersonal, neutral; the client functions as an actor in the system. In fact, the system is a tool of power, a totality of rules and roles, neither good nor bad, but amoral. Knopf Zastrow explains that democracy, humanism, and respect for uniqueness give drive to the helper, the relation is based on volunteerism, while the bureaucratic system is hierarchical, value deficient, and emotionally neutral (Zastrow 1995: 43). Often, the solution to this dilemma is that the social worker personalizes bureaucracy by constructing an enemy picture, but since the system is amoral, it is meaningless to attribute personal qualities to it - we should treat it as a structure.

In connection with the voluntary and obligatory clients, the question arises how to motivate the client. According to the stereotypical view, the voluntary client is actually the well-behaving client who is conscientious, requests and accepts help, is motivated, open to cooperation, able to make decisions freely, and the cooperation is less burdened with certain ethical dilemmas. This is the opposite of the obligatory client, who is identified with the image of the unmotivated client (Pataki 2008: 6-7). According to Lorenz (2008: 98), the success of the intervention largely depends on the social-political context it is implemented in: "If the political program imposes a punitive approach, which aims to separate the deserving from the undeserving, then users will refuse even the friendliest approach, and what is more, they will regard a 'friendly policesocial worker' with much more suspicion, and the loss of confidence will be even more destructive when the mask of helpfulness peels off".

Dominelli also draws attention to the fact that in many cases the compulsory cooperation is realized with individuals who come from a social stratum where freedom is in fact limited (qtd by Pataki 2008: 10). Thus, public policy often 
forces individuals to build up obligatory relations with social services and social workers. In this perspective, social relations are thus reflected in the relationship between the social worker and client, and the social workers themselves can be considered as the delegates of the dominant groups (Pataki 2008: 10).

The following is a brief description of the main findings of three researches on child protection, which intend to reveal the professional mentalities in child protection, reflecting on the dysfunctional operation of the child protection system as well. In fact, the tangible professional crisis in child protection derives from the undefined nature of the profession as to what extent it is pedagogy or social work in nature. We believe that competencies of social work type and the core values of the profession may provide an important frame of reference for child protection personnel.

\section{The state as good parent?}

In 2014, the University of Debrecen conducted a research built on quantitative and qualitative methods, which was designed to explore the principles and technical concepts generally related to corporate parental and care-taking responsibilities that define practical work among child protection professionals (Rácz 2014). The research drew attention to a number of dysfunctional operations; the followings will highlight those that strain the integrity of the professional framework.

During the placement procedure in child protection care, when the most appropriate place is determined for children in the care system according to their needs, all the interviewed experts claim that typically the available places determine the proposal of a committee of experts, rather than children's real needs. Decisions motivated by financial reasons override a child's personal interests, which appear not only in the selection of a place for appropriate support capacity but in the case of choosing between foster or institutional care forms, since it is a fundamental statement that foster care is significantly cheaper, and the experts handle it as a high priority argument in the decisionmaking process. When examining foster and institutional care, the experts take it as the most important starting point that the two subsystems should not be contrasted with each other even when comparing their operating characteristics or assessing their efficiency, that is, they are complementary care forms of services to substitute a family. It is a wrong idea that either form of care should have over-dominance although they agree that the application of certain guidelines, setting priorities (for example, the guiding principle of placing the under 12 age-group to foster care) are necessary, but their practical application should reflect the actual real-life situations more accurately than the current practice does. They believe that the profession should formulate the advantages 
and disadvantages arising from the peculiarities of the two forms and should be able to use these as means.

Unfortunately, in many cases, the child protection system works through ad-hoc decision-making processes with clear underfunding in the background. In the early 2000s, the conversion process started, that is, the replacement of large institutions - as turning point in reorganizing the system - was a process without sufficient funds. As compared to mass placement, the institutions of the apartment home structure typically operate in small settlements without advanced infrastructure, which poses new challenges to children and professionals alike, and in the absence of appropriate training the professionals were not able to provide adequate support for children in their trust.

It is a serious problem in child protection that professional, substantive changes are mostly private initiatives, thanks to a dedicated expert. There is no quality control in the specialist care of the current system. In addition, professional regulations would be vitally important because they would determine what professionals should know and, simultaneously, what a particular institution or care can provide for children or parents.

\section{Indicators and evaluation models in the child protection system}

The Rubeus Association's 2015 research consisted of two parts: 1) the definition of service field indicators and specifications in the child protection system; 2) preparing evaluation models that record the requirements for child care in the provided services (e.g. children's home care, disabled care, foster care), and record results as requirements are met at the level of the actors of the system (e.g. child, parent, tutor, guardian, foster parent), and in the broadest sense the specific child care services and their relationship with other social subsystems (e.g. education, health). The test of evaluation models often exposed weaknesses, professional misconduct, or even ethical misconduct. We may interpret these for all three actor fields:

1) Level of professionals

Focusing on the strengths is often ignored; the professionals can better identify the negatives, which, however, make professional work more difficult. It is a problem that certain child protection positions are full of tensions; for example, the co-operation between foster care advisor - child protection guardians -, children's homes or foster care staff. It is important to clarify the individual competence boundaries, the responsibilities as well as how and by what professional tools and methods the professionals can mobilize to ensure the basic goals of child protection. During the assessment of the nature and content of professional work, the question arises as to whether the care assistants (e.g. foster care counsellor, child welfare guardian) perform a helping or a controlling type of work. 


\section{2) Level of biological family}

Based on the results of the research, actually, the information on children are often different, arbitrary for the members of the target group (children and parents) and professionals in these cases. The biological parent is lost in the administration, often feels threatened and blamed, while the system does not provide an adequate support. The entire system of child protection lacks the service level of assistances that aim at strengthening parental competencies.

3) Level of clients

The road to specialized care as well as the way out of there, even if planned, is not interpreted for the different actors. Young people's vision of future is uncertain; thus, they are under-motivated and unfocused, they drift with events, and they are passive players in shaping their own destiny. In children and young adults, there appear some cases of "adopted impotence", which in all cases relates to the conservation of the conditions they face when entering child protection care, that is, unsolved traumas, disorder in family relations, and in general their meagre network of connections.

The research draws attention to the important role of ethics in addition to the legislative framework, protocols, and standards, which can solve dilemmas encountered in practical operation and find the right treatments (Rubeus Association 2016).

\section{Social professional image and self-reflections}

The University of Debrecen undertook another research between 2014 and 2015, titled The Political and Sociological Use of Narratives of Victimhood in Europe and Hungary, which covers four thematic areas - social, child protection, health, and legal areas - and investigates experts' opinions on the profession, the experts themselves, and the clients. The social and child protection areas were based on Papp and Rácz's (2015) evaluation study of an analysis of semi-structured interviews with twenty professionals. The helpers came from different areas such as family assistance, child welfare, school social work, children's homes, or homeless services. The results of the research bring attention to the fact that over the last 20-30 years social and child protection professionals' pervasive role has become endangered before clarification, and co-operation is based on fear in many cases, the fundamental values of the profession are violated in practice, and authoritarianism has become the basis for cooperation with the clients representing the power.

The main results of the research showed that the expectations are enormous for the professionals on the part of the maintainer, operator, local leader as well as the clients. Professionals experience fear on a daily basis: they are afraid that they make wrong decisions that may turn the client's life into tragedy, while 
the leaders give no professional guidance in these matters, although they should have a key role in that the helpers have space to consider each case, to question guidelines; in general, to have the intention to respond to the individual problem areas and to formulate new methods and procedures for particular problem areas. The interviewed social and child protection experts unanimously agreed that it is crucial for professionals to assess their limits because not every case of failure is their fault. Professionals believe that to cooperate with clients and representatives of power is conflict-ridden, often including local leaders, not only the decision makers. They cannot fulfill their role as helpers in such a vulnerable position, and when they fail they perceive it as if they are themselves the victims of the system. As long as the helping framework, the expectations are not clear, social workers and child protection professionals will only take on a the role of martyr in the spirit of moral superiority.

\section{Summary}

Lorenz (2008) points out that social work is actively involved in the transformation of the welfare state and the restructuring of welfare conditions; therefore, it should be assessed whether the available methodological framework is sufficient to manage the problems and, more broadly, "to promote the social conditions to viability in the context of globalization" (Lorenz 2008: 97). The direction of development is the establishment and strengthening of an activating and motivating social work and child protection, which are based on the most important core values of helping and, at the same time, adapt to social changes and public policy expectations (Montana 2008). The methodology must be renewed by giving more space to the issues of human autonomy and action and freedom of choice.

The situation is given: either the social and child protection professions will become the servants of public policy and politics without criticism or a competent action plan must be prepared to reflect on the conditions in the marginalized groups of society. In Lorenz's words, “the basic trust emerges as a dialectical interaction between self-confidence and trust towards the social environment (...)”. The children and their parents need not a repressive stability but a contractual framework that reduces the unpredictability of life with the support of a reliable, accountable, and effective helping system. "What would be useful to learn from the market - as opposed to the planned economy that has clearly failed - is the process by which the unpredictability can be reduced" (Lorenz 2008: 99-100).

In our study, we have argued against converting the helping professions into an instrument of power to recruit and regulate the electoral army reserves. 
However, the identification and the implementation of the rules of good conduct require the existence of ethics for the helper. The conflict between society and personal values, social interests and the interests of the client (in the case of a child, even against the parents), competing values and issues of loyalty all require moral decisions, which need a platform. Helpers should actually enjoy their profession: by providing challenges, different management strategies for each client, opportunities to develop knowledge, applied methods and selfknowledge, and by offering space to deploy new services when new needs arise (Zastrow 1995: 50).

\section{References}

Asquith, Steward, Clark, Chris, Waterhouse, Lorraine. 2005. The Role of the Social Worker in the $21^{\text {st }}$ Century - A Literature Review. Scottish Executive. (http://www.gov.scot/resource/doc/47121/0020821.pdf).

Beran, Ferenc. 2007. Etika. Budapest: Gondolat Kiadó.

Fónai, Mihály, Kiss, János, Fábián, Gergely. 1996. Szociális munkás szakos hallgatók pályaképének néhány eleme. Esély 1: 114-134.

Gardner, Howad, Csíkszentmihályi, Mihály, Damon, William. 2008. Jó munka. Budapest: Lexecon Kiadó.

Heller, Ágnes. 1996. Morálfilozófia. Budapest: Cserépfalvi Kiadó. 1994. Általános etika. Budapest: Cserépfalvi Kiadó.

Hexendorf, Edit, Farkas, Vilmos, S. Hámori, Antónia, Pusztai, Ferenc, P. Hidvégi, Andrea, Kubínyi, László. 1976. A magyar nyelv történeti-etimológiai szótára 1. (ed. Kiss Lajos). Budapest: Akadémiai Kiadó.

International Federation of Social Work (IFSW). 2014. A szociális munka globális definíciója. Esély 6: 96-100.

Juhász, József, Kovalovszky, Miklós, O. Nagy, Gábor, Szőke, István. 1972. Magyar értelmezó kéziszótár A-Zs. Budapest: Akadémiai Kiadó.

Kecskés, Pál. 2003. Az erkölcsi élet alapjai. Budapest: Jel Kiadó.

Krémer, Balázs. 2009. Bevezetés a szociálpolitikába. Budapest: Napvilág Kiadó. Lorenz, Walter. 2008. A szociális munka és az új társadalmi rend: a szolidaritást gyengítő neoliberalizmus elutasítása. Esély 1: 91-101.

Márfai Molnár, László. 2017. Túlélés és megértés. Alkalmazott etika és esztétika. Budapest: L’Harmattan Kiadó.

Müller, C. Wolfgang. 1992. Hogyan vált a segítségnyújtás hivatássá? Budapest: T-Twins.

Nagy, Krisztina. 2011. „Bizonytalanok” és „próbálkozók”. A szociális képzések hallgatóinak karaktertípusai és a képzés jelentősége a szakmai szocializációban. Esély 1: 100-116. 
2009. Professzionalizáció- és professzió-elméletek a segítő hivatások tükrében. Esély 2: 85-105.

Nyíri, Tamás. 2003. Alapvetó etika. Budapest: Szent István Társulat.

Papp, Eszter, Rácz, Andrea. 2015. Vigyázat! Emberek! Szociális és gyermekvédelmi szakemberek szakmaképének vizsgálata. Metszetek 3: 45-61. (http://metszetek. unideb.hu/files/metszetek\%202015_3\%20racz\%2045-61_0.pdf).

Parrot, Lester. 2010. Values and Ethics in Social Work. Exeter: Learning Matters. Pataki, Éva. 2008. Kontroll és segító funkció a szociális munkában. A kötelezett kliensekkel való munka elméleti és gyakorlati kérdései. (Study Report) (http:// szm.sze.hu/downloadmanager/download/nohtml/1/id/3035/m/4169).

Pierson, John, Thomas, Martin. 2011. Dictionary of Social Work. Berkshire: Open University Press, McGraw-Hill House.

Rácz, A. (ed.). 2016. Indikátorok és evaluációs modellek a gyermekvédelmi szakellátásban. Budapest: Rubeus Egyesület (in press).

2014. Jó szülő-e az állam? - fejlesztési igények a gyermekvédelmi szakellátás professzionalizációjáért. In: A. Rácz (ed.), Jó szülő-e az állam? - A corporate parenting terminus gyakorlatban való megjelenése. Budapest: Rubeus Egyesület. 215-245. (http://rubeus.hu/wp-content/uploads/2014/05/ CPnemzetkozi_2014_final.pdf).

Sárkány, P. 2011. A szociális munka mint alkalmazott etika. Szociális Szemle 1-2: 7-18.

Torma, András (n.d.). A közigazgatás funkciói és feladatai. (http://www.jogikar. uni-miskolc.hu/projectSetup/files/koi/kozig1/a-kozigazgatas-funkcioi-esfeladatai-igazgatasszervezo.pdf).

Vossenkuhl, Wilhelm. 2007. A jó lehetősége. Etika a 21. században. Iskolakultúra 3: $37-50$.

Zastrow, Charles. 1995. Mit tegyünk, hogy a szociális munka élvezetes hivatás legyen? (part. 2). Esély 5: 42-59. 